\title{
PENGARUH PENERAPAN METODE INTERVENSI SEMANTIK DIVERGEN TERHADAP AFASIA TRANSKORTIKAL MOTORIS
}

\author{
Santi Komaladini", Popon, Resti Selisthiany \\ Prodi Diploma Tiga Terapi Wicara Politeknik Al Islam Bandung \\ Email: santikomaladini@politeknikalislam.ac.id ,
}

\begin{abstract}
ABSTRAK
Penelitian ini bertujuan untuk mengetahui penerapan metode intervensi semantik divergen pada klien afasia transkortikal motoris pasca stroke jenis kelamin laki-laki usia 44 tahun di Rumah Sakit Umum Daerah Cibabat. Metode penelitian yang digunakan adalah eksperimen penelitian studi kasus yang bertujuan untuk mengetahui keadaan subjek sebelum dan sesudah intervensi melalui terapi. Pengumpulan data dilakukan melalui tahapan WOTS, yaitu (1) wawancara dengan orang tua klien, (2) Observasi secara langsung terhadap klien, (3) melakukan tes kepada klien, dan (4) studi dokumen rekam medis pasien. Hasil penelitian setelah dilakukan terapi dengan menggunakan metode intervensi semantik divergen sebanyak 15 kali pertemuan diperoleh hasil baik dengan penilaian menyebut tingkat kata pada kata benda. Simpulan yang diperoleh bahwa metode intervensi semantik divergen berpengaruh untuk menyebut tingkat benda.
\end{abstract}

Kata kunci: afasia transkortikal motoris. metode intervensi semantik divergen, pengaruh

\begin{abstract}
This study aims to determine the application of the divergent semantic intervention method in motor transcortical aphasia clients after stroke, male gender aged 44 years at the Cibabat Regional General Hospital. The research method used is a case study research experiment that aims to determine the condition of the subject before and after intervention through therapy. Data collection was carried out through the WOTS stage, namely (1) interviews with the client's parents, (2) direct observation of the client, (3) conducting tests on the client, and (4) studying the patient's medical record document. The results of the research after doing therapy using the divergent semantic intervention method for 15 meetings obtained good results by assessing the level of words on nouns. The conclusion is that the divergent se
\end{abstract}

Keywords: divergent semantic intervention methods, influence, transcortical motor aphasia.

\section{PENDAHULUAN}

Menurut WHO, stroke adalah gangguan fungsi otak yang terjadi secara mendadak dengan tanda dan gejala klinis lokal maupun global yang berlangsung selama 24 jam atau lebih dan dapat menyebabkan kematian akibat gangguan peredaran darah (lesi vascular). 
Salah satu di antara bentuk gangguan tersebut adalah afasia. Afasia merupakan gangguan berbahasa. Gejala yang dialami pasien menunjukkan gangguan dalam memproduksi dan/atau memahami bahasa. Efek dasar afasia terjadi pada pemrosesan bahasa di tingkat integratif yang lebih tinggi. Keumuman yang terjadi biasanya afasia dapat menimbulkan hilangnya kemampuan berbahasa setelah kerusakan otak.

Dalam kajian terapi wicara terdapat berbagai metode yang menjelaskan penanganan terhadap kasus afasia. Salah satu bentuk penanganan tersebut adalah intervensi semantik divergen. Metode ini, mengharuskan pasien untuk menggali ide berupa ungkapan kata yang pasti.

Oleh sebab itu diperlukan suatu informasi untuk pemberian tata laksana bagi klien afasia transkortikal motoris yang berjenis kelamin laki-laki usia 44 tahun di Rumah Sakit Umum Daerah Cibabat.

Tujuan penelitian ini yang hendak di capai adalah mendeskripsikan pengaruh penerapan metode Intervensi Semantik Divergen untuk meningkatkan kemampuan menyebut benda pada pasien Afasia Transkortikal Motoris pasca stroke jenis kelamin laki-laki usia 44 tahun di Rumah Sakit Umum Daerah Cibabat"

\section{Jenis Penelitian}

\section{METODOLOGI PENELITIAN}

Penelitian yang dilakukan adalah jenis eksperimental, yaitu penelitian terhadap seseorang yang diduga menderita sesuatu gangguan, dengan memberikan intervensi. Pendekatan ini didahului dengan pretest melalui intervensi, yaitu sebuah perlakuan yang tersistem dan dapat diukur tingkat keberhasilan intervensi tersebut. Menurut Nazir (2005), langkah-langkah penelitiannya sebagai berikut, (1) tes awal, (2) kegiatan terapi, (3) tes akhir, (4) peneliti membandingkan jumlah tes akhir dan tes awal, (5) selisihnya dijadikan kriteria keberhasilan.

Tabel 1 Pre test dan Post test

\begin{tabular}{ccc}
\hline Pre test & Perlakuan & Post test \\
\hline $\mathrm{T}_{0}$ & $\mathrm{X}$ & $\mathrm{T}_{1}$ \\
\hline & $\mathrm{T}_{1-} \mathrm{T}_{0}=$ Jumlah Peningkatan & \\
\hline
\end{tabular}

Keterangan:

$\mathrm{T}_{0}$ : sebelum dilakukan terapi $\mathrm{X}$ : Perlakuan atau kegiatan terapi $\quad \mathrm{T}_{1}:$ sesudah dilakukan terapi

\section{Desain Penelitian}

Penelitian yang dilakukan menggunakan penelitian studi kasus. Dimulai dengan melakukan assesment terhadap pasien untuk mengetahui diagnosa dan permasalahan yang dialami oleh pasien. Dilanjutkan dengan melakukan tes awal guna mengukur kemampuan pasien sebelum terapi sampai dengan setelah terapi melakukan tes akhir, kemudian dibandingkan antara tes awal dan tes akhir agar mengetahui progress yang dicapai oleh pasien selama terapi. 


\section{Tempat dan Waktu Penelitian}

Penelitian ini dilaksanakan di Rumah Sakit Umum Daerah Cibabat Cimahi dan di rumah pasien. Adapun waktu penelitian dilakukan selama dua bulan sejak Januari 2019 sampai Maret 2019.

\section{Jenis dan Sumber Data}

Jenis data yang digunakan dalam penelitian ini merupakan data primer dan sekunder. Data diperoleh secara langsung dari objek penelitian melalui observasi, wawancara, dan tes serta menggali informasi terkait melalui referensi buku, materi kuliah, internet, dan jurnal.

Penelitian ini menerapkan metode terapi yang dilakukan langsung kepada subjek penelitian yaitu salah satu pasien afasia transkortikal motoris di Rumah Sakit Umum Daerah Cibabat dengan identitas sebagai berikut:

$\begin{array}{ll}\text { Nama } & : \text { Tn. AM } \\ \text { Jenis Kelamin } & : \text { Laki-laki } \\ \text { Tempat, tanggal lahir } & : \text { Bandung, 16 Januari 1975 } \\ \text { Usia } & : \text { 44 tahun } \\ \text { Suku bangsa } & : \text { Indonesia } \\ \text { Bahasa } & : \text { Bahasa Indonesia } \\ \text { Agama } & : \text { Islam } \\ \text { Alamat } & : \text { Jl. Pertambangan blok E No. 49, Cibeber, Cimahi Selatan. }\end{array}$

Teknik dan Instrumen Pengumpulan Data

Tabel 2 Teknik, Instrumen, Responden, dan Indikator Penelitian

\begin{tabular}{|c|c|c|c|c|}
\hline No & $\begin{array}{c}\text { Teknik } \\
\text { pengumpulan } \\
\text { data }\end{array}$ & Instrumen & Responden & Indikator \\
\hline 1. & $\begin{array}{l}\text { Inform Consent } \\
\text { dan wawancara }\end{array}$ & $\begin{array}{l}\text { Format } \\
\text { Informed } \\
\text { Consent dan } \\
\text { wawancara } \\
\text { (guide } \\
\text { interview) }\end{array}$ & $\begin{array}{l}\text { Keluarga } \\
\text { pasien }\end{array}$ & $\begin{array}{l}\text { Sebagai persetujuan } \\
\text { dilakukan pengambilan data } \\
\text { dan untuk mendapatkan data } \\
\text { berupa; identitas, keluhan } \\
\text { yang terlihat dan atau yang } \\
\text { dirasakan, faktor yang } \\
\text { berkaitan dengan penyebab } \\
\text { yang terdapat pada diri } \\
\text { pasien. }\end{array}$ \\
\hline 2. & Observasi & $\begin{array}{l}\text { Format } \\
\text { observasi }\end{array}$ & Pasien & $\begin{array}{l}\text { Untuk mendukung hasil } \\
\text { wawancara yang telah } \\
\text { dilakukan meliputi kondisi } \\
\text { fisik, kemampuan motorik, } \\
\text { sensorik, bahasa, wicara, } \\
\text { suara, irama kelancaran, } \\
\text { menelan serta kondisi yang } \\
\text { relevan lainnya. }\end{array}$ \\
\hline 3. & $\begin{array}{l}\text { Pemeriksaan Alat } \\
\text { Wicara }\end{array}$ & Format PAW & Pasien & $\begin{array}{l}\text { Untuk melihat keutuhan dan } \\
\text { kemampuan struktur } \\
\text { maupun fungsi organ wicara } \\
\text { berupa bibir, gigi, lidah, } \\
\text { langit-langit keras, langit- } \\
\text { langit lunak, palatopharinx, }\end{array}$ \\
\hline
\end{tabular}




\begin{tabular}{|c|c|c|c|c|}
\hline & & & & $\begin{array}{l}\text { fauces, nasal cavities, } \\
\text { pergerakan oral } \\
\begin{array}{l}\text { disengaja. } \\
\text { lisang }\end{array}\end{array}$ \\
\hline 4. & $\begin{array}{lr}\text { Tedyva } & \text { Tes } \\
\text { Dysartria dan } & \text { dan } \\
\text { Apraksia Verbal) }\end{array}$ & $\begin{array}{l}\text { Buku Tedyva } \\
\text { dan format tes } \\
\text { Tedyva }\end{array}$ & Pasien & $\begin{array}{l}\text { Dilakukan untuk } \\
\text { memperoleh data dari pasien } \\
\text { yang mungkin mengalami } \\
\text { disartria }\end{array}$ \\
\hline 5. & Token Test & $\begin{array}{l}\text { Format Token } \\
\text { Test }\end{array}$ & Pasien & $\begin{array}{l}\text { Untuk menentukan adanya } \\
\text { gangguan reseptif. }\end{array}$ \\
\hline 6. & $\begin{array}{lr}\text { TADIR } & \text { (Tes } \\
\text { Afasia } & \text { untuk } \\
\text { Diagnosa, } & \\
\text { Informasi } & \text { dan } \\
\text { Rehabilitasi) } & \end{array}$ & $\begin{array}{l}\text { Buku Tadir dan } \\
\text { format tes Tadir }\end{array}$ & Pasien & $\begin{array}{l}\text { untuk menentukan diagnosa } \\
\text { afasia/ bukan afasia dan } \\
\text { termasuk sindroma afasia } \\
\text { yang mana serta menjadi } \\
\text { titik tolak ukur penanganan } \\
\text { terapi wicara. }\end{array}$ \\
\hline 7. & Tes Suara & $\begin{array}{l}\text { Format } \\
\text { Suara }\end{array}$ & Pasien & $\begin{array}{l}\text { Untuk mengetahui apakah } \\
\text { terjadi kelainan pada nada, } \\
\text { kenyaringan dan kualitas } \\
\text { suara pasien saat ini. }\end{array}$ \\
\hline 8. & $\begin{array}{ll}\text { Tes } & \text { Irama } \\
\text { Kelancaran } & \end{array}$ & $\begin{array}{ll}\text { Format } & \text { tes } \\
\text { irama } & \\
\text { kelancaran } & \end{array}$ & Pasien & $\begin{array}{l}\text { Untuk mengetahui apakah } \\
\text { terjadi kelainan dalam } \\
\text { berirama (berupa } \\
\text { perpanjangan, pengulangan, } \\
\text { penghentian ataupun } \\
\text { penahanan) pada saat } \\
\text { bernyanyi, berbicara ataupun } \\
\text { berhitung. }\end{array}$ \\
\hline 9. & $\begin{array}{l}\text { Anamnesa Makan } \\
\text { dan Minum, Tes } \\
\text { Menelan }\end{array}$ & $\begin{array}{l}\text { - Format } \\
\text { wawancara } \\
\text { makan dan } \\
\text { Minum, } \\
\text { - Format status } \\
\text { Fungsi } \\
\text { menelan } \\
\text { - Pemeriksaan } \\
\text { klinis disfagia }\end{array}$ & Pasien & $\begin{array}{l}\text { Untuk mengetahui apakah } \\
\text { ada kelainan (gangguan } \\
\text { menelan) yang terjadi pada } \\
\text { saat pasien menelan cairan, } \\
\text { mengunyah dan menelan } \\
\text { makanan melalui wawancara } \\
\text { kepada keluarga pasien. }\end{array}$ \\
\hline 10. & Studi Dokumen & - & $\begin{array}{l}\text { Hasil CT- } \\
\text { Scan }\end{array}$ & $\begin{array}{l}\text { Untuk bahan pelengkap dan } \\
\text { penguat data yang } \\
\text { didapatkan dari ahli lain }\end{array}$ \\
\hline 11. & $\begin{array}{l}\text { Tes Awal dan Tes } \\
\text { Akhir }\end{array}$ & $\begin{array}{ll}\text { Format } & \text { tes } \\
\text { awal dan } & \text { tes } \\
\text { akhir } & \end{array}$ & Pasien & $\begin{array}{l}\text { Untuk mengetahui } \\
\text { keberhasilan terapi yang } \\
\text { dicapai rengan } \\
\text { membandingkan kedua hasil } \\
\text { tes tersebut. }\end{array}$ \\
\hline 12. & $\begin{array}{l}\text { Alat } \\
\text { Terapi }\end{array}$ & $\begin{array}{l}\text { - Tensimeter } \\
\text { - Stetoskop } \\
\text { - Stopwatch }\end{array}$ & Pasien & $\begin{array}{l}\text { Untuk mengukur tekanan } \\
\text { darah pasien } \\
\text { Untuk menghitung jeda yang } \\
\text { mungkin terjadi saat } \\
\text { pelaksanaan terapi }\end{array}$ \\
\hline
\end{tabular}




\section{HASIL DAN PEMBAHASAN}

\section{Hasil Wawancara}

Berdasarkan hasil wawancara yang telah dilakukan oleh penulis pada tanggal 12 Januari 2019 diperoleh keterangan bahwa terjadi penurunan kesadaran selama 18 jam di kamarnya. Pasien dibawa ke Rumah Sakit Mitra Kasih dan di dapat keterangan bahwa pasien terkena stroke. Tekanan darah pasien pada saat itu adalah 180/130 mmHg. Selang waktu satu hari, pasien dirujuk ke Rumah Sakit Umum Daerah Cibabat Cimahi untuk rawat inap karena keluarga pasien tidak menyanggupi masalah biaya. Pasien dirawat selama 7 hari di Rumah Sakit Umum Daerah Cibabat. Pada saat itu kondisi pasien diinfus dan menggunakan Naso Gastro Tube (NGT). Ketika sadar, pasien tidak mampu menyampaikan sesuatu dengan verbal maupun non verbal dan hanya ditawarkan ketika ingin sesuatu. Setelah 2 hari pasien baru mampu mengucapkan 'ir' maksudnya air minum.

Selanjutnya pasien disarankan untuk melakukan terapi wicara oleh dokter setelah pulang dari rumah sakit. Lalu pasien dirujuk melakukan terapi wicara di Rumah Sakit Umum Daerah Cibabat Cimahi. Pasien mengeluhkan kesulitan untuk mengutarakan sesuatu. Ketika wawancara keluarga pasien mengeluhkan pasien sering tidak nyambung ketika mengobrol dengan orang lain.

Saat ini pasien mengalami kesulitan dalam mengutarakan sesuatu, membentuk kalimat dan menjawab pertanyaan yang rumit sehingga pasien masih melakukan terapi wicara di Rumah Sakit Umum Daerah Cibabat Cimahi.

\section{Hasil Tes}

Hasil pemeriksaan alat wicara, struktur dan fungsi organ wicara klien berada pada peringkat 1 yang berarti normal, tidak mempengaruhi wicara dan tidak mengalami kelainan.

Hasil Pemeriksaan Alat Wicara (pergerakan oral yang disengaja) yang telah dilakukan penulis sebanyak 20 item, 12 item mampu dilakukan klien secara normal tanpa diberi contoh, 7 item mampu dilakukan klien secara normal dengan diberi contoh dan 1 item tidak mampu dilakukan, kemungkinan tidak akan mempengaruhi kemampuan wicara. Pergerakan Oral yang Disengaja klien berada diskala 8. Dengan demikian disimpulkan bahwa struktur organ wicara klien dalam keadaan baik. Hasil TEDYVA didapatkan bahwa kemampuan bicara pasien mengalami gangguan.

Hasil pengamatan dan tes yang dilakukan berkaitan dengan sindroma yang berhubungan dengan suara sebagai berikut: Dari hasil pengamatan dan tes yang dilakukan pada saat klien meniru ucapan dan berbicara terdengar berintonasi (nada). Saat klien berbicara kualitas suara klien terdengar normal tidak ada suara nasal. Pengamatan dan tes yang dilakukan, suara klien terdengar nyaring.

Studi dokumen adalah suatu cara pemeriksaan dengan mempelajari hasil pemeriksaan-pemeriksaan ahli yang terkait. Apabila tidak ada dan dirasa perlu, hendaknya terapis wicara merujuk ke ahli tim terkait sesuai dengan kebutuhan klien (Peraturan Menteri Kesehatan No. 81 tentang Standar Pelayanan Terapi Wicara Tahun 2014). 


\section{Analisis Data}

\section{PEMBAHASAN}

Berdasarkan hasil wawancara yang telah dilakukan oleh penulis pada tanggal 12 Januari 2019 diperoleh keterangan bahwa terjadi penurunan kesadaran selama 18 jam di kamarnya. Pasien dibawa ke Rumah Sakit Mitra Kasih dan di dapat keterangan bahwa pasien terkena stroke akibat pecahnya pembuluh darah di otak. Tekanan darah pasien pada saat itu adalah 180/130 mmHg. Selang waktu satu hari, pasien dirujuk ke Rumah Sakit Umum Daerah Cibabat Cimahi untuk rawat inap karena keluarga pasien tidak menyanggupi masalah biaya. Pasien dirawat selama 7 hari di Rumah Sakit Umum Daerah Cibabat. Pada saat itu kondisi pasien diinfus dan menggunakan Naso Gastro Tube (NGT). Ketika sadar, pasien tidak mampu menyampaikan sesuatu dengan verbal maupun non verbal dan hanya ditawarkan ketika ingin sesuatu. Setelah 2 hari pasien baru mampu mengucapkan 'ir' maksudnya air minum.

Menurut Purwani (2017), seiring bertambahnya usia, akan ada satu atau beberapa bagian dari dinding pembuluh darah yang melemah. Terjadinya pembengkakan pada salah satu dinding pembuluh darah yang lemah bisa mengakibatkan pembuluh darah tersebut pecah. Selain usia, faktor yang beresiko untuk terjadinya stroke adalah faktor keturunan dan secara umum terjadi karena penderita memiliki tekanan darah tinggi atau hipertensi.

Pasien melakukan pemeriksaan CT-Scan untuk mengetahui adanya kerusakan pada otak. Didapatkan adanya infark lakuler multiple di daerah substansia alba periventrikuler lateralis bilateral dan ganglia basalis bilateral.

Unit CT konvensional bekerja dengan posisi pasien yang terbaring di meja saat sedang dipindai. Meja bergerak maju dan keluar dari tabung untuk mencakup area yang dibutuhkan. Saat semua data diterima, lalu dikumpulkan untuk membuat suatu dataset. Ini dapat dimanipulasi untuk melihat informasi pada berbagai sudut pandang yang berbeda (gonzalez, 2016: 1-2).

Infark otak-kematian neuron disebabkan oleh tiadanya oksigen atau nutrien atau terganggunya metabolisme (Harsono, 2015: 71). Substansia alba yaitu jaringan saraf putih yang membentuk bagian penghantar impuls pada otak dan medula spinalis, sebagian besar tersusun dari serat-serat saraf bermielin.

Menurut Irianto dalam buku Anatomi dan Fisiologi substansia alba dari hemisferium serebri merupakan bagian putih. Otak besar mengandung baik serabut-serabut saraf bermielin dengan berbagai jenis ukuran maupun neuroglia. Ketiga tipe serabut saraf yang bermielin membentuk pusat dari hemisferium serebri: serabut transversal, serabut proyeksi dan serabut asosiasi.

Struktur sub kortikal terdiri dari: (1) Ganglia basal. Melaksanakan fungsi motoris dengan merinci dan mengkoordinir gerakan dasar, gerak halus (terampil), dan sikap tubuh. (2) hipotalamus. Pusat tertinggi integrasi dan koordinasi sistem saraf otonom dan terlibat dalam pengolahan perilaku insting.

Berdasarkan Pemeriksaan Alat Wicara pada fungsional organ wicara bibir pasien tidak ada tandatanda kelainan pada anatomi bibir. Bisa melakukan Protusi tetapi, tidak sempurna ketika bibir digerakan ke samping kiri. Saat tersenyum bibir pasien terlihat simetris.

Berdasarkan hasil token tes, asien mampu mengerjakan instruksi benar dengan skor 22 dari total 36 item yang diteskan. Itu berarti pasien mengalami gangguan bahasa reseptif sedang. 
Berdasarkan hasil tes TADIR, pada poin informasi pribadi, menyebut, pemahaman bahasa lisan, dan menulis tingkat fonologi mendapat skor 4 (sedikit terganggu). Sedangkan pada poin menamai tingkat kalimat pasien mendapat skor 2 (sangat tergangu).

Menurut Irianto dalam buku Anatomi dan Fisiologi substansia alba dari hemisferium serebri merupakan bagian putih. Otak besar mengandung baik serabut-serabut saraf bermielin dengan berbagai jenis ukuran maupun neuroglia. Ketiga tipe serabut saraf yang bermielin membentuk pusat dari hemisferium serebri: serabut transversal, serabut proyeksi dan serabut asosiasi.

Struktur sub kortikal terdiri dari: (1) Ganglia basal. Melaksanakan fungsi motoris dengan merinci dan mengkoordinir gerakan dasar, gerak halus (terampil), dan sikap tubuh. (2) hipotalamus. Pusat tertinggi integrasi dan koordinasi sistem saraf otonom dan terlibat dalam pengolahan perilaku insting.

Berdasarkan Pemeriksaan Alat Wicara pada fungsional organ wicara bibir pasien tidak ada tandatanda kelainan pada anatomi bibir. Bisa melakukan Protusi tetapi, tidak sempurna ketika bibir digerakan ke samping kiri. Saat tersenyum bibir pasien terlihat simetris.

Berdasarkan hasil token tes, asien mampu mengerjakan instruksi benar dengan skor 22 dari total 36 item yang diteskan. Itu berarti pasien mengalami gangguan bahasa reseptif sedang. Berdasarkan hasil tes TADIR, pada poin informasi pribadi, menyebut, pemahaman bahasa lisan, dan menulis tingkat fonologi mendapat skor 4 (sedikit terganggu). Sedangkan pada poin menamai tingkat kalimat pasien mendapat skor 2 (sangat tergangu).

\section{Hasil Pelaksanaan Terapi}

Metode yang digunakan adalah Intervensi Semantik Divergen yang dikembangkan oleh Chapey pada tahun 1981. Yang mendjadi dasar pemilihan dari metode Intervensi semantik devergen adalah bahwa dalam kehidupan sehari-hari, pasien afasia harus menggali berbagai macam ide sendiri terutama dalam komunikasi verbal. Chapey menggarisbawahi pentingnya tugas-tugas yang memungkinkan lebih dari satu respon dalam penanganan afasia, terutama untuk melatih penemuan kata.

Materi dipilih untuk mencapai keberhasilan program jangka pendek, penulis memberikan materi berupa intruksi untuk pasien menyebutkan benda dengan kategori : Benda yang ada di kamar tidur (Kasur, bantal, guling, selimut, lemari), Kategori benda yang ada di ruang makan (piring, gelas, sendok, garpu dan mangkok), Benda yang ada di kamar mandi (sab8n, sikat gigi, pasta gigi, shampo, dan gayung), benda yang ada di ruang keluarga (sofa, TV, Karpet, lemari TV, Hiasan/pajangan).

Berikut ini adalah langkah-langkah metode Intervensi semantic divergen, diantaranya sebagai berikut:

- Pasien diberikan stimulus berupa intruksi untuk menyebutkan benda yang ada di suatu ruangan.

- Ketika pasien tidak mampu atau mampu menyebutkan benda dengan jeda lebih dari 5 detik, maka diberi petunjuk berupa fungsi benda.

Metode intervensi semantik divergen digunakan untuk melatih penemuan kata pada pasien afasia ringan. Dalam kehidupan sehari-hari, pasien afasia harus menggali berbagai macam ide sendiri terutama dalam komunikasi verbal. Chapey menggarisbawahi pentingnya tugas-tugas yang 
memungkinkan lebih dari satu respon dalam penanganan afasia, terutama untuk melatih penemuan kata.

Tabel 3 Tes Awal yang Dilakukan kepada Klien

\begin{tabular}{|c|c|c|c|}
\hline \multirow[t]{2}{*}{ No } & \multirow[t]{2}{*}{ Stimulus } & \multicolumn{2}{|c|}{ Respon } \\
\hline & & +2 & TM \\
\hline 1. & Kasur & & 0 \\
\hline 2. & Bantal & & 0 \\
\hline 3. & Guling & & 0 \\
\hline 4. & Selimut & & 0 \\
\hline 5. & Lemari & & 0 \\
\hline 6. & Piring & & 0 \\
\hline 7. & Gelas/cangkir & & 0 \\
\hline 8. & Sendok & & 0 \\
\hline 9. & Garpu & & 0 \\
\hline 10. & Mangkok & & 0 \\
\hline 11. & Sabun & & 0 \\
\hline 12. & Sikat gigi & & 0 \\
\hline 13. & Pasta gigi & & 0 \\
\hline 14. & Shampo & & 0 \\
\hline 15. & Gayung & & 0 \\
\hline 16. & Sofa & & 0 \\
\hline 17. & TV & & 0 \\
\hline 18. & Karpet & & 0 \\
\hline 19. & Lemari TV & & 0 \\
\hline 20. & Hiasan/pajangan & & 0 \\
\hline Jumlah & & & 0 \\
\hline
\end{tabular}

Prosedur yang dilakukan oleh penulis untuk menilai keberhasilan terapi jangka harian yaitu dengan cara membandingkan antara tes awal sebelum melakukan terapi dan tes akhir setelah melakukan terapi.

Terapi dilakukan selama 20x pertemuan terapi dan 1x evaluasi dengan program Intervensi Semantik Divergen dilakukan dengan mengamati perkembangan kemampuan menyebutkan benda yang terdiri dari 4 kategori dan berjumlah 20 item dikali 1 (skor maksimal yang di peroleh) yaitu 20 poin maksimal yang harus diperoleh pasien. Untuk menentukan perbandingan sebelum dan sesudah terapi yaitu:

Tabel 4 Perbandingan Tes Awal dan Tes Akhir

\begin{tabular}{llrrrrr} 
& \multicolumn{1}{c}{ Stimulus } & \multicolumn{3}{c}{ Respon } & \multicolumn{3}{c}{ Respon } \\
\cline { 3 - 6 } & & S & TM & S & J & TM \\
\hline 1. & Kasur & & 0 & 1 & & \\
\hline 2. & Bantal & 0 & 1 & \\
\hline 3. & Guling & 0 & 1 & \\
\hline 4. & Selimut & 0 & 1 & \\
\hline 5. & Lemari & & 0 & 1 & \\
\hline 6. & Piring & 0 & 1 & \\
\hline 7. & Gelas/cangkir & & 0 & 1 & \\
\hline
\end{tabular}




\begin{tabular}{clccc}
\hline 8. & Sendok & 0 & 1 & \\
\hline 9. & Garpu & 0 & 1 & \\
\hline 10. & Mangkok & 0 & & 0,5 \\
\hline 11. & Sabun & 0 & 1 & \\
\hline 12. & Sikat gigi & 0 & 1 & \\
\hline 13. & Pasta gigi & 0 & 1 & \\
\hline 14. & Shampo & 0 & 1 & \\
\hline 15. & Gayung & 0 & & 0,5 \\
\hline 16. & Sofa & 0 & & 0,5 \\
\hline 17. & TV & 0 & 1 & \\
\hline 18. & Karpet & 0 & 1 & \\
\hline 19. & Lemari TV & 0 & 1 & \\
\hline 20. & Hiasan/pajangan & 0 & 1 & \\
\hline Jumlah & 0 & 17 & 1,5 \\
\hline
\end{tabular}

Untuk menentukan peningkatan perbandingan sebelum dan sesudah terapi, penulis menggunakan:

\begin{tabular}{|c|}
\hline Jumlah tes akhir - Jumlah tes awal \\
\hline $18,5-0=18,5$ \\
\hline
\end{tabular}

Hasil tes awal pasien mendapat nilai 0 poin dan hasil tes akhir pasien mendapat 18,5 poin.

Berdasarkan hasil tes akhir diketahui pasien memperoleh peningkatan sebanyak 18,5 poin.

Dalam menentukan skala keberhasilan menggunakan nilai tes awal:

$$
\frac{\text { Nilai hasil tes awal } \times 100 \%}{\text { jumlah poin maksimal }}=\frac{0 \times 100 \%}{20}=0 \%
$$

Nilai tes akhir :

$$
\frac{\text { Nilai hasil tes akhir } \times 100 \%}{\text { jumlah poin maksimal }}=\frac{18,5 \times 100 \%}{20}=92,5 \%
$$

\begin{tabular}{cccc}
\hline No & Kenaikan Respon Benar & Skala Presentase & Skala keberhasilan \\
\hline $\mathbf{1}$ & $16-20$ & $76 \%-100 \%$ & Sangat Berhasil \\
\hline $\mathbf{2}$ & $11-15$ & $51 \%-75 \%$ & Berhasil \\
\hline $\mathbf{3}$ & $6-10$ & $26 \%-50 \%$ & Kurang Berhasil \\
\hline $\mathbf{4}$ & $1-5$ & $0-25 \%$ & Tidak Berhasil \\
\hline
\end{tabular}


Berdasarkan hasil diatas diketahui bahwa pasien mengalami peningkatan dalam kemampuan 9 benda mengalami peningkatan sebanyak 18,5 poin dengan persentase $92,5 \%$, dengan demikian dapat disimpulkan bahwa terapi sangat berhasil.

\section{KESIMPULAN}

Berdasarkan hasil terapi kepada pasien yang berdurasi selama 45 menit, frekuensi 3-4 kali seminggu sebanyak 20 kali pertemuan untuk meningkatkan kemampuan menyebut benda dengan menggunakan metode Intervensi Semantik Divergen diperoleh peningkatan kemampuan sebanyak 18,5 poin. Persentase keberhasilan $92,5 \%$ (sangat berhasil).

Penulis dapat menyimpulkan bahwa metode Intervensi Semantik Divergen untuk meningkatkan kemampuan menyebut benda pada kasus Afasia Transkortikal Motoris yang ditemukan penulis terutama untuk meningkatkan kemampuan menyebut tingkat kata mengalami peningkatan. Kriteria keberhasilan terapi yang telah penulis buat, terapi yang telah penulis lakukan kepada pasien termasuk kategori "Sangat Berhasil".

Hal ini didukung oleh angket pernyataan sesudah terapi, menyatakan pasien puas pada pelayanan dan hasil terapi yang dilakukan 20 kali pertemuan. Keberhasilan terapi juga dapat dipengaruhi oleh kesadaran pasien akan gangguan yang pasien alami dan motivasi dari diri pasien sendiri untuk bisa lebih baik lagi. Pasien rajin terapi ke rumah sakit dan latihan sendiri dirumah pada waktu luang. Dari lingkungan keluarga pun mendukung pasien untuk menjadi lebih baik lagi.

\section{DAFTAR PUSTAKA}

Akademi Terapi Wicara-YWB. 2010. Manajemen Klinik I. Jakarta: Akademi Terapi Wicara.

Dharmaperwira-Prins, Reni. 1996. Tadir Tes Afasia Untuk Diagnosis Informasi Rehabilitasi. Jakarta: Balai Penerbit Fakultas Kedokteran Universitas Indonesia.

Dharmaperwira-Prins, Reni. 2002. Afasia Deskripsi Pemeriksaan dan Penanganan. Jakarta: Balai Penerbit Fakultas Kedokteran Universitas Indonesia.

Gonzalez, Shawneen M. 2016. Prinsip Dasar Interpretasi Cone Beam Computer Tomography. Jakarta: Buku Kedokteran EGC.

Harsono. 2015. Buku Ajar Neurologi Klinis. Yogyakarta: Gadjah Mada University Press.

Irianto, Koes. 2017. Anatomi dan Fisiologi Edisi Revisi.

Lumbantobing. 2013. Neurologi Klinik Pemeriksaan Fisik dan Mental. Jakarta: Badan Penerbit Fakultas Kedokteran Universitas Indonesia.

Notoatmodjo, Soekidjo. 2010. Metode Penelitian Kesehatan. Jakarta: Rineka Cipta.

Novark, Patricia. 2015. Kamus Saku Kedokteran Dorland Edisi 29. Singapure: Elsevier.

Peraturan Menteri Kesehatan Republik Indonesia Nomor 81. 2014. Standar Pelayanan Terapi Wicara.

Peraturan Menteri Kesehatan Republik Indonesia Nomor 585. 1989. Persetujuan Tindakan Medik atau Informed Consent.

Purwani, Dwi Rahayu. 2017. Stroke's Home Care. Yogyakarta: Healthy.

Shultz, Judith Robillard. 2009. Speech-Language Pathologist MGH-MUHC.

Sugiyono. 2015. Metode Penelitian Tindakan Komprehensip. Bandung: Alfabeta. 